\title{
SYNTHESIS, SOLVATOCHROMISM, ELECTRONIC STRUCTURE AND NONLINEAR OPTIC PROPERTIES OF QUINOLIN-8-YL 2-HYDROXYBENZOATE
}

\author{
Ayşegül Gümüiş,*, Yadigar Gülseven Sıdır², İsa Sıdır², Selçuk Gümüşs \\ ${ }^{1}$ Van Yuzuncu Yil University, Faculty of Science, Department of Chemistry, 65080 Van, Turkey \\ ${ }^{2}$ Bitlis Eren University, Faculty of Arts and Science, Department of Physics, 13000 Bitlis, Turkey \\ gumusa@gmail.com agumus@yyu.edu.tr
}

\begin{abstract}
Quinolin-8-yl 2-hydroxybenzoate (QHB) was synthesized and its physical and electronic properties were investigated both experimentally and theoretically. The electronic structure and spectral behavior were determined by using UV-vis absorption and fluorescence spectra in 11 different polarity solvent media. The absorption band observed at $306-308 \mathrm{~nm}$ is attributed to $\pi-\pi^{*}$ and $\mathrm{n}-\pi^{*}$ electronic transitions due to its geometric structure in the solution phase. Solvatochromism of QHB was investigated by using Kamlet-Taft and Catalan methods based on the linear solvation energy relationships (LSER). The Kamlet-Taft solvatochromic model indicates that spectral shifts of absorption and fluorescence spectra are effectively controlled by dispersion-polarization forces which describe the non-specific interactions. The solvatochromic model of Catalan states that solute-solvent interaction is governed by solvent polarity in the absorption spectra and by solvent acidity in the fluorescence spectra. Non-specific interactions have a greater effect on fluorescence spectra compared to absorption spectra. Computational calculations were performed by the application of the B3LYP/6-311+(d,p) level of theory. Conformational analysis performed for QHB showed five staggered conformers on torsional potential energy surfaces. Accordingly, the most stable conformer was found to be the one involving intra-molecular hydrogen bonding. The geometry of the other conformers indicated that the absence of hydrogen bonding gave rise to relatively higher energy. Frontier molecular orbitals (HOMO, LUMO) and non-linear optical (NLO) parameters were calculated by B3LYP/6-311+(d,p) level of theory. Theoretical UV spectra both in gas and solution phases were also investigated by TDDFT-CAM-B3LYP/6-311+(d,p) level of theory.
\end{abstract}

Keywords: hydroxyquinoline; solvatochromism; bathochromic effect; spectroscopy; nonlinear optical properties; TDDFT

\section{СИНТЕЗА, СОЛВАТОХРОМИЗАМ, ЕЛЕКТРОНСКА СТРУКТУРА И НЕЛИНЕАРНИ ОПТИЧКИ СВОЈСТВА НА ХИНОЛИН-8-ИЛ 2-ХИДРОКСИБЕНЗОАТ}

Извршена е синтеза и експериментално и теориски беа испитани електронските својства на хинолин-8-ил 2-хидроксибензоат (QHB). Електронската структура и спектралните својства беа определени со употреба на UV-vis апсорпциона спектроскопија и флуоресцентни спектри во 11 растворувачи со различна поларност. Апсорпционата лента што се јавува на 306-308 nm се должи на електронските премини $\pi-\pi^{*}$ и $\mathrm{n}-\pi^{*}$ поради геометриската структура во раствор. Солватохромизмот на QHB беше испитан со употреба на методите на Kamlet-Taft и Catalan засновани на зависноста на линеарна енергија на солватација (LSER). Солватохроматскиот модел на Kamlet-Taft укажува дека спектралните поместувања на апсорпцијата и флуоресцентните спектри ефективно се контролирани од дисперзионо-поларизациските сили што опишуваат неспецифични интеракции. Солватохроматскиот модел на Catalan укажува дека интеракциите од типот растворена супстанција-растворувач се управувани од поларноста на растворувачот во апсорпционите спектри и од киселоста на растворувачот во флуоресцентните спектри. 
Неспецифичните интеракции имаат поголем ефект врз флуоресцентните спектри во споредба со апсорпционите спектри. Компјутерските пресметки беа извршени со примена на теоретското ниво B3LYP/6-311+(d,p). Конформациската анализа на QHB покажува пет наизменични конформери на површината на торзиона потенцијална енергија. Според тоа, најстабилен конформер е оној кога се јавува молекулско водородно сврзување. Геометријата на другите конформери укажува дека отсуството на водородно сврзување се одразува со релативно поголема енергија. Граничните молекулски орбитали (HOMO, LUMO) и нелинеарните оптички (NLO) параметри беа пресметани на теоретското ниво B3LYP/6-311+(d,p). Испитани беа и теоретските UV спектри во гасна фаза и во раствор, и тоа на теоретското ниво TDDFT-CAM-B3LYP/6-311+(d,p).

Клучни зборови: хидроксихинолин; солватохромизам; батохроматски ефект; спектроскопија; нелинеарни оптички својства; TDDFT

\section{INTRODUCTION}

The quinoline ring and its derivatives have attracted considerable interest in fundamental research areas due to their strong chemical and biological activities, in addition to their specific properties. Their wide ranges of pharmaceutical applications are because of their cytotoxic, bactericide and fungicide properties [1-5]. They have also found applications as chelating ligands for the preparation of various photo- and electroluminescent metal complexes [6-7], and as highly effective fluorescent chemosensors for metal cations [89] because of their high fluorescent yield, rapid structure and wide energy gaps. Thus, it is very important to reach a detailed understanding of the electronic, photophysical and solvatochromic properties of quinoline derivatives.

Knowledge of the solute-solvent interaction during electronic transitions and electronic structures of molecules provides important information on how electrons behave actively in photo-physical and photo-chemical processes. In addition, solvatochromism gives information about the organic electronic material properties of molecules. It is worth noting that wavelength shifts (bathochromic and hypsochromic effects), depending on the solvent medium of electronic transitions, can be explained by fitting on a quantitative model (polarity, bipolarity function and hydrogen donor and acceptor or different physical parameters) $[10,11]$.

Researchers have been interested in acquiring the structural and spectroscopic properties of various molecules using both experimental and computational methods for many years. The theoretical calculations using density functional theory (DFT) have been employed to study molecular properties such as structural, molecular orbital, spectroscopic and photo-physical properties [12-
15]. The geometric and spectroscopic investigations, such as frequency, UV-vis and NMR data provide valuable information regarding the structure and conformation of molecules [16]. Polarizability and first order hyper-polarizability provide information about nonlinear optical (NLO) properties of a material [17]. Charge distribution analysis, absorption-emission characteristics and thermal properties, along with the molecular electrostatic potential surface analysis, give a clear understanding of the structural, reactivity and spectral characteristics of the molecule under study [18]. The dipole moment characteristic of a molecule is quite beneficial in designing NLO compounds [19], and studying reaction mechanisms [20] and electronic distribution within the molecule [21]. Quantitative measurement of solute-solvent interactions of molecules is also a popular area of research [22, 23].

The main objective of this study is to clarify the solute-solvent interaction types and determine the contribution of each solvent parameter on the absorption and fluorescence wavelength shifts. By the solvatochromic shift methods, it is possible to understand the specific and non-specific interactions between solute and solvent. Inter- and intramolecular active interaction centers of QHB make it interesting for solute-solvent interactions. Emerging non-linear optical and electronic properties are also important for the application of QHB in many technological fields.

In this work, the synthesis of new quinolin8-yl 2-hydroxybenzoate (QHB) has been described. Moreover, absorption and fluorescence spectral properties, electronic transitions and solvatochromism of the title compound have been investigated experimentally in detail. The conformational stability, non-linear optical parameters and electronic structure along with the frontier molecular orbitals have been analyzed theoretically. 


\section{EXPERIMENTAL SECTION}

\subsection{General}

All of the solvents, as spectroscopic grade, are commercially available from Sigma-Aldrich. The solvent impurity control was performed in steady-state fluorescence apparatus. ${ }^{1} \mathrm{H}$ NMR and ${ }^{13} \mathrm{C}$ NMR spectra were recorded in $\mathrm{CDCl}_{3}$ on a Bruker Spectrospin Avance DPX-400 spectrometer. ${ }^{1} \mathrm{H}(400 \mathrm{MHz})$ and ${ }^{13} \mathrm{C}$ NMR were recorded in $\mathrm{CDCl}_{3}$ and the chemical shifts are expressed in ppm relative to $\mathrm{CDCl}_{3}\left(\delta 7.26\right.$ and 77.0 for ${ }^{1} \mathrm{H}$ and ${ }^{13} \mathrm{C}$ NMR, respectively) as the internal standard. LC-MS/MS measurements were performed on the Thermo Scientific Q-Exactive instrument. Melting points were measured by the Stuart SMP3 instrument. Ultraviolet-visible (UV-vis) absorption spectra were recorded on a Perkin-Elmer Lambda35 UV-vis Spectrophotometer over a wavelength range of $200-800 \mathrm{~nm}$. Steady-state fluorescence spectra were recorded on a Perkin-Elmer LS-55 Model Fluorescence Spectrophotometer by choosing $310 \mathrm{~nm}$ excitation wavelength. The excitation source was a long life Xenon flash lamp. All measurements were performed using a $1 \mathrm{~cm} \times 1 \mathrm{~cm}$ quartz cell at room temperature. The solution was prepared as $11.2 \mathrm{mM}$. The absorption and fluorescence spectral band maxima were determined by Gaussian curve fit analysis using the OriginPro 8.0 program. Flash column chromatography was performed by using thick-walled glass columns and silica gel (60-mesh; Merck). The reactions were monitored by thin-layer chromatography (TLC) using Merck 0.2-mm silica gel 60 F254 analytical aluminum plates, and visualized by UV light. All extracts were dried over anhydrous magnesium sulphate and solutions were concentrated under reduced pressure by using a rotary evaporator.

Kamlet-Taft parameters (dielectric constant $\varepsilon$, refractive indices $n, \mathrm{H}$-bonding donor capacity $\alpha$, H-bonding acceptor capacity $\beta$ ) and Catalan parameters (solvent polarity $S P$, solvent dipolarity $S d P$, acidity of solvent $S A$, basicity of solvent $S B$ ) are taken from the literature [24-30].

\subsection{Synthesis of quinolin-8-yl 2-hydroxybenzoate}

To a solution of salicylic acid $(2.1 \mathrm{~g}, 15$ mmol) in $10 \mathrm{ml} \mathrm{SOCl}_{2}, 2$ drops of DMF were added. The solution was refluxed at $70^{\circ} \mathrm{C}$ for $24 \mathrm{~h}$. Then, the excess $\mathrm{SOCl}_{2}$ was evaporated and salicylic acid chloride was obtained. In a separate flask, 8-hydroxyquinoline (1.45 g, $10 \mathrm{mmol}$ ) was dissolved in $20 \mathrm{ml}$ benzene and cooled to $0{ }^{\circ} \mathrm{C}$.
Then, $1 \mathrm{ml}$ of $\mathrm{Et}_{3} \mathrm{~N}$ was added to the reaction mixture. After $30 \mathrm{~min}$. stirring, salicylic acid chloride was added to the mixture slowly and refluxed for 5 $h$. The solvent was evaporated and the crude product was purified by flash column chromatography using ethyl acetate/hexane (1:4) as the eluent [31].

Yellow solid. (2.44 g, 92\% yield); mp 109$11{ }^{\circ} \mathrm{C}[31] ;{ }^{1} \mathrm{H}$ NMR $\left(\mathrm{CDCl}_{3}, 400 \mathrm{MHz}\right): \delta 10.64$ (bs, $1 \mathrm{H}), 8.90(\mathrm{dd}, J=1.7$ and $4.2 \mathrm{~Hz}, 1 \mathrm{H}), 8.27$ (dd, $J=1.7$ and $8.0 \mathrm{~Hz}, 1 \mathrm{H}), 8.20(\mathrm{dd}, J=1.7$ and 8.3 $\mathrm{Hz}, 1 \mathrm{H}), 7.78$ (dd, $J=1.6$ and $8.0 \mathrm{~Hz}, 1 \mathrm{H}), 7.65-$ $7.53(\mathrm{~m}, 3 \mathrm{H}), 7.44(\mathrm{dd}, J=4.22$ and $8.3 \mathrm{~Hz}, 1 \mathrm{H})$, 7.08 (dd, $J=1.1$ and $8.6 \mathrm{~Hz}, 1 \mathrm{H}), 7.04-7.00(\mathrm{~m}$, $1 \mathrm{H}) ;{ }^{13} \mathrm{C} \mathrm{NMR}\left(\mathrm{CDCl}_{3}, 400 \mathrm{MHz}\right): \delta 168.6,161.7$, $150.7,146.8,140.9,136.2,136.1,131.0,129.5$, $126.4,126.3,122.0,121.5,119.6,117.9,112.5$. LC-MS/MS Anal. Calcd for $\mathrm{C}_{16} \mathrm{H}_{11} \mathrm{NO}_{3}[\mathrm{M}+\mathrm{H}]^{+}$: $\mathrm{m} / \mathrm{z}$ 266.08117. Found: $\mathrm{m} / \mathrm{z}$ 266.08218. CAS Number [42206-69-9].

\subsection{Linear solvation energy relationship (LSER) method}

Regression analysis is the process of statistical equations of relations between a dependent variable and an independent variable (simple regression) or multiple independent (multiple regression) variables. In regression analysis, the relationship between variables is called linear regression. Multiple regression equation for a system with multiple variables in regression analysis is given as below (Eq. 1).

$$
\mathrm{Y}=\mathrm{B}_{0}+\mathrm{B}_{1} \mathrm{X}_{1}+\mathrm{B}_{2} \mathrm{X}_{2}+\ldots . \mathrm{B}_{\mathrm{N}} \mathrm{X}_{\mathrm{i}} \ldots \ldots
$$

In here, $\mathrm{B}_{0}, \mathrm{~B}_{1}, \mathrm{~B}_{2}, \mathrm{~B}_{\mathrm{N}}$ are coefficients, and $\mathrm{Y}$ is the dependent variable, $\mathrm{X}_{1}, \mathrm{X}_{2}, \ldots, \mathrm{X}_{\mathrm{i}}$ are independent variables [32]. An application field of regression analysis used in mathematical and statistical fields is molecular science. The method called LSER was obtained by using the multiple linear regression equation. The effects of the solvent polarity on the spectral properties of the solute are investigated by the Kamlet-Taft and Catalan parameters, which are the Linear Solubility Energy Relations (LSER) methods [25, 27-28, 30, 33]. The changes in the electronic structure of molecules under UV light are examined using multiple linear regression analysis (LSER), which is generated by different parameters of the solvents. The LSER model obtained by using the parameters of Kamlet-Taft solvatochromism was used in these studies. The multiple parameter equation used as the solvatochromic parameter is as follows (Eq. 2) $[25,27-28]$. 


$$
v_{\max }=v_{0}+\mathrm{C}_{1} f(n)+\mathrm{C}_{2} f(\varepsilon)+\mathrm{C}_{3} \beta+\mathrm{C} 4 \alpha
$$

Here, the maximum absorbance $\left(v_{\max }\right)$ was investigated by dependence on $\mathrm{H}$-bond acceptor capability $(\beta)$, H-bond donor capability $(\alpha)$, polarizability $f(n)=\left(n^{2}-1\right) /\left(n^{2}+2\right)$ described by refraction index functions and the polarity $f(\varepsilon)$ described by dielectric function $f(\varepsilon)=(\varepsilon-1) /(\varepsilon+2)$, respectively $[25,30]$.

Another LSER method used to study the electronic structure of molecules was derived by using Catalan parameters and is given as follows (Eq. 3):

$$
v_{\max }=v_{0}+\mathrm{C}_{5} S P+\mathrm{C}_{6} S d P+\mathrm{C} 7 S A+\mathrm{C}_{8} S B
$$

Here, the maximum absorbance $\left(v_{\max }\right)$ is dependent on the solvent polarity $S P$, solvent polarizability $S d P$, solvent acidity $S A$, and solvent basicity $S B[30,34]$. In LSER calculations, SPSS Statistics Version 20 was used.

\subsection{Computational method}

The three-dimensional ground state $\left(\mathrm{S}_{0}\right)$ geometries of all compounds were optimized in the gas phase without any symmetry restrictions by using DFT [35] implemented hybrid functional B3LYP with the Gaussian 09W [36] package program. B3LYP is composed of Becke's three parameter exchange functional (B3) [37] and the non-local correlation functional by Lee, Yang and Parr (LYP) [38]. The basis set used for all atoms was $6-311+G(d, p)$ in both density functional theory (DFT) and time-dependent density functional theory (TD-DFT).

After geometry optimization calculations in the gas phase, the stabilities of all of the structures in various solvents have also been investigated. This is practically important since it is well known that these kinds of molecules should exist in the body fluid of humans or animals, meaning that how to describe the interaction between the solute and the surrounding solvent molecules and the corresponding effect on the stability is significant. Traditionally, the self-consistent reaction field (SCRF) model is normally used to describe the effect of medium on chemical reactions. In this model, the microscopic information of molecular interaction between biomolecules and its surrounding molecules were neglected. Instead, the small water clusters were used to model solvent effects on some properties of the solute, such as tautomeric stabilities. Solvent effects were explored by using the SCRF method, and the polarizable continuum model (PCM) method was employed [39].
For each compound, vibrational analysis was carried out using the same basis set employed in the corresponding geometry optimizations. The frequency analysis of none of the compounds yielded any imaginary frequencies, indicating that the structure of each molecule corresponds to at least a local minimum on the potential energy surface. The normal mode analysis was performed for $3 \mathrm{~N}-6$ vibrational degrees of freedom, with $\mathrm{N}$ being the number of atoms in the molecule.

The vertical excitation energies and oscillator strengths were obtained for the lowest triplet and singlet transitions at the optimized ground state equilibrium geometries by using TD-DFT with CAM-B3LYP/6-311+G(d,p) level of theory [40]. These computations have been performed using the PCM method in various solvents. Optimized ground state structures were utilized to obtain the electronic absorption spectra, including maximum absorption wavelengths, oscillator strengths, and main configuration assignment by using TD-DFT.

\section{RESULTS AND DISCUSSION}

\subsection{Synthesis of $Q H B$}

Acid chlorides are valuable precursors for the synthesis of various ester moieties. Salicylic acid chloride was synthesized from salicylic acid by using $\mathrm{SOCl}_{2}$ and drops of DMF. The hydroxy unit on the quinoline skeleton was reacted with this salicylic acid chloride in alkaline medium to construct quinolin-8-yl 2-hydroxybenzoate (Scheme 1) [31].

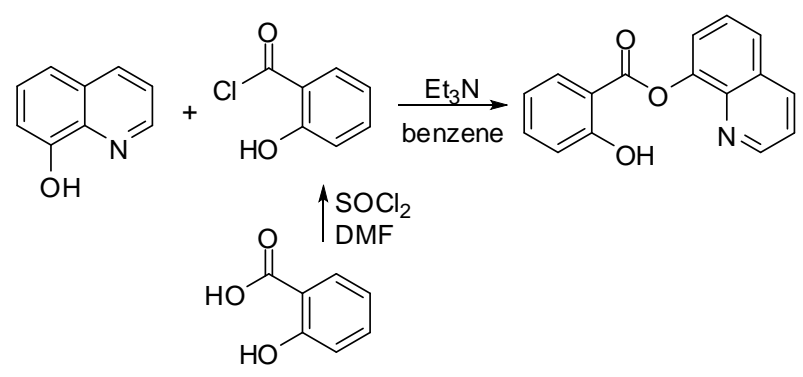

Scheme 1. Synthesis of QHB

\subsection{Conformational stability and molecular geometry}

The ground state geometry of the compound represents a minimum point at the potential energy surface. When it is difficult to determine the correct global minimum, performing a conformational 
analysis is necessary. In the present case, the conformational analysis of the compound has been employed around the bond connecting the carbonyl and benzene in order to observe the effect of intramolecular hydrogen bonding on the stability of the whole system. The B3LYP/6-311+G(d,p) level of theory was performed in the gas phase in order to scan the dihedral angle to obtain energies of the conformers. During the scan process, the geometry of the whole system was relaxed, meaning that none of the bonds or angles were frozen. In Figure 1 , the energy profile of the conformational analysis is given. The most stable conformer on the $2 \mathrm{D}$ potential energy surface was obtained when hydroxyl hydrogen interacts with the carbonyl to form a hydrogen bond. Moreover, at this conformation, benzoate function is twisted $73^{\circ}$ from planarity to the quinoline moiety (Fig. 1a).
As expected, hydrogen bonding interactions cannot be observed in the highest energy conformation (Figure 1b). The stability of the system increased upon hydrogen bonding interactions between the hydrogen of the hydroxyl group and the benzoate oxygen through 1.88 Á distance (Fig. 1c). At this point, the benzoate moiety is totally perpendicular to the quinoline plane. A two sided hydrogen bonding; i) hydrogen of the hydroxyl group and the benzoate oxygen through $1.91 \AA$ distance and ii) interaction with the quinoline nitrogen with a distance of $2.15 \AA$, gave rise to the second most stable conformation (Fig. 1d). Interestingly, at the closest distance (1.88 $\AA$ ) between quinoline nitrogen and the hydrogen of the hydroxyl group, the energy of the system increased to a second maximum point (Fig. 1e), which may be attributed to the loss of conjugation of the carbonyl with phenoxy moiety.

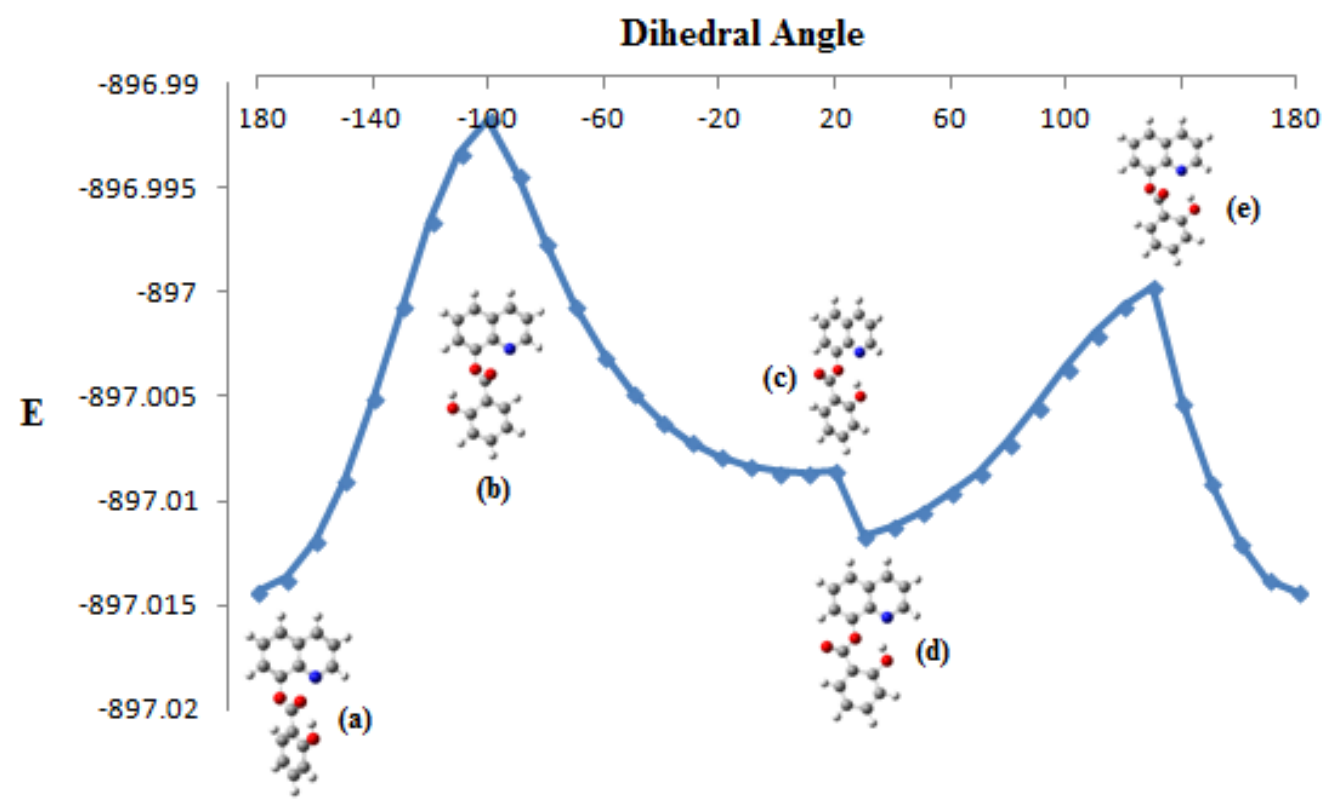

Figure 1. Conformational analysis of QHB (energy is in Hartree unit)

\subsection{Solvent effect on the absorption and fluorescence spectra}

The UV-vis absorption and steady state fluorescence spectra of quinolin-8-yl 2-hydroxybenzoate $(\mathrm{QHB})$ in various solvents with different polarities are given in Figure 2. Absorption and fluorescence maximum wavelengths are presented in Table 1. As can be seen from absorption spectra, QHB exhibits three sharp and narrow bands with fine structured characteristics. These bands are centered at 301-304 nm, 306-308 nm and 313-315 $\mathrm{nm}$, respectively. The fine structure observed in the
$\mathrm{UV}$-vis spectra is a result of inter-molecular interaction formed between the solvent and oxygen and nitrogen atoms of quinoline. DFT-B3LYP/6$311+\mathrm{G}(\mathrm{d}, \mathrm{p})$ optimized geometrical structure indicates that the $-\mathrm{O}-----\mathrm{H}$ distance is $1.88 \AA$ for the stable conformer of QHB and $1.91 \AA$ for the high energy structure. By the same method, the $-\mathrm{H}----$ $\mathrm{N}$ distance is calculated to be $2.15 \AA$. In such a system the -O-----H interaction distance is expected to be $\sim 1.70 \AA$. Elongation of $\sim 0.18 \AA$ is confirmation of the competition between $-\mathrm{O}-\mathrm{H}$ and $\mathrm{C}=\mathrm{O}$ (see Fig. 3). 

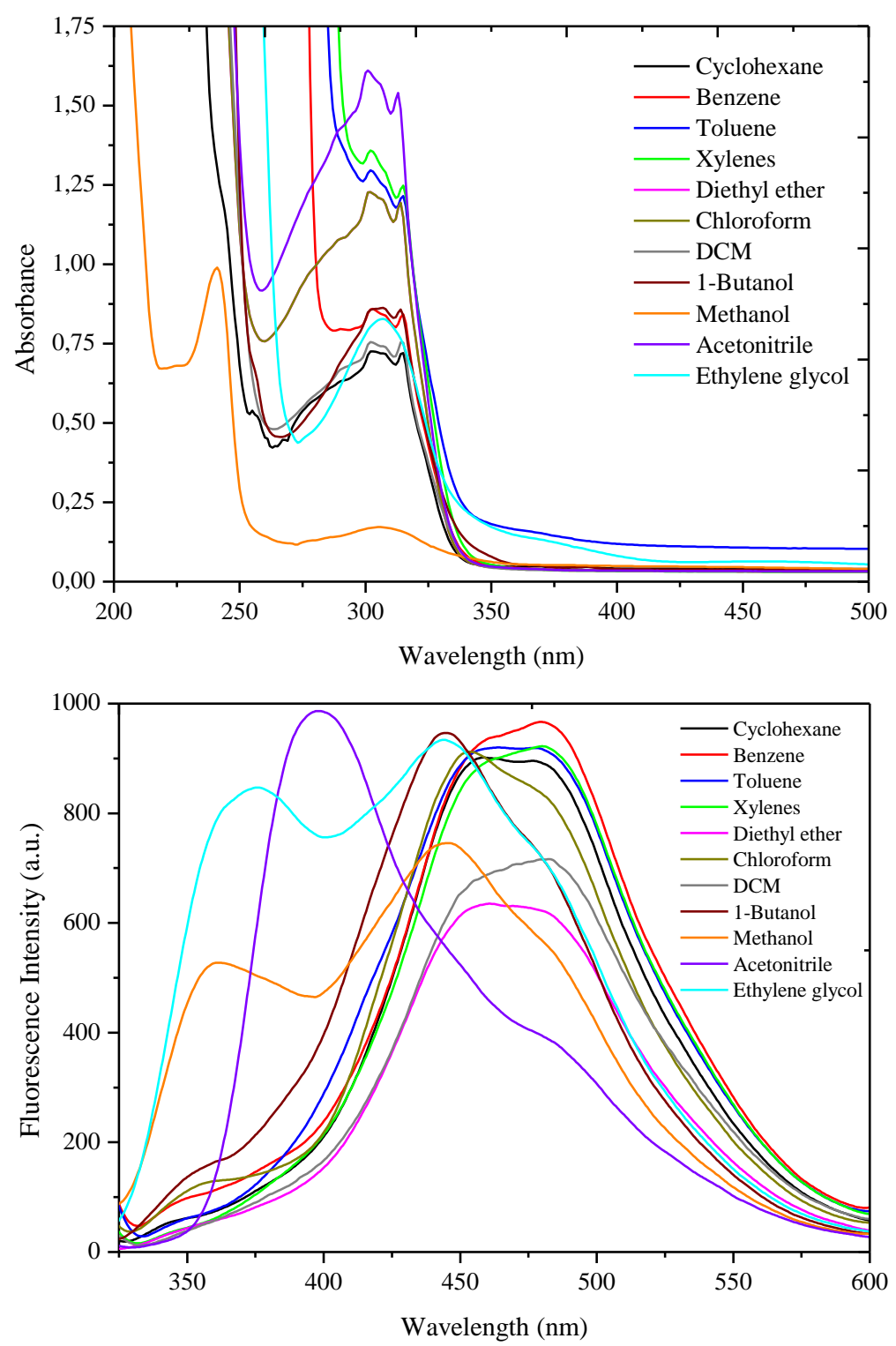

Fig. 2. UV-vis absorption and fluorescence spectra of QHB in various solvents with different polarities<smiles>c1ccc2c(c1)ONOC2Oc1cccc2cccnc12</smiles>

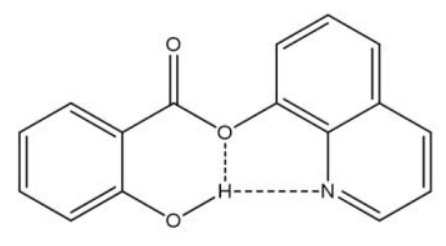
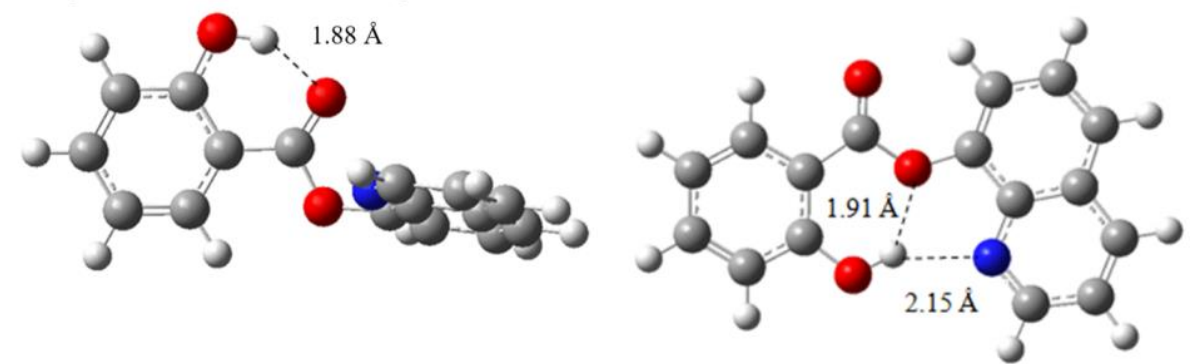

Total energy $E=-897.008222113$ Hartree Relative energy $E=0.158 \mathrm{eV}$

Total energy $E=-897.014031716$ Hartree Relative energy $E=0.000 \mathrm{eV}$

(and $-\mathrm{N}-\mathrm{-H}$ intra-molecular $\mathrm{H}-\mathrm{b} 0 \mathrm{nding}$

Fig. 3. B3LYP/6-311+G(d, p) optimized 3D structure along with $-\mathrm{O}---\mathrm{H}$ and $-\mathrm{N}---\mathrm{H}$ intra-molecular H-bonding and energies of quinolin-8-yl 2-hydroxybenzoate (QHB) 
It is worth noting that fine structures are not observed in the polar protic solvents, methanol $(\alpha=$ $0.93, \beta=0.62)$ and ethylene glycol $(\alpha=0.90, \beta=$ 0.52 ) which form specific interactions with QHB (see Fig. 4). This demonstrates that the fine structure in the UV-vis spectra is the result of electronic transitions occurring between special states. Interestingly, $\mathrm{UV}$-vis spectrum of QHB in polar protic 1-butanol shows a fine structure that can be attributed to the solvent properties, such as the fact that 1-butanol has relatively long alkyl chain and pushes electrons towards the media. Nonetheless, the hydrogen bond donor $(\alpha=0.79)$ and acceptor $(\beta=0.88)$ capacity of 1 -butanol is close to each other.

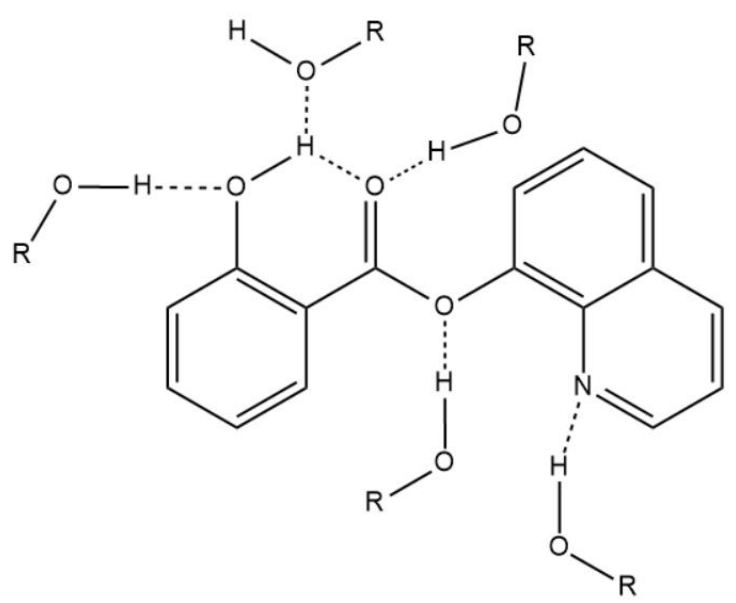

Fig. 4. Inter-molecular QHB-alcohol interactions

In QHB molecules, both $\pi-\pi^{*}$ and $n-\pi^{*}$ electronic transitions are possible due to $\pi$ electrons located in aromatic rings and lone-pair electrons on oxygen and nitrogen atoms. There are seven lonepair electrons which are responsible for $n-\pi^{*}$ transitions. The first absorption band can be attributed to the $\pi-\pi^{*}$ transition resulting from the $\pi$ electron delocalization in the aromatic rings. The second absorption band is observed because of the rearrangement of $\pi$ electrons over the entire molecular system. Additionally, intra-molecular -O-H-----O hydrogen bonding interactions leading to $\mathrm{n}$ electrons are included in the electron delocalization process over the whole molecular system. Electron delocalization channels depending on the enol-keto tautomerism are shown in Figure 5. Therefore, it can be said that this band corresponds to a mixture of $\pi-\pi^{*}$ and $n-\pi^{*}$ electronic transitions. However, this can be considered to be global electronic transitions of QHB. The longest wavelength absorption band is described as having an $n-\pi^{*}$ character existing from the interaction between lone-pair electrons of QHB and solvent media.
Differences between maximum wavelengths recorded according to solvents are found to be very small: 2-3 nm for each of the absorption bands.

This indicates that absorption bands are not sensitive to solvent.
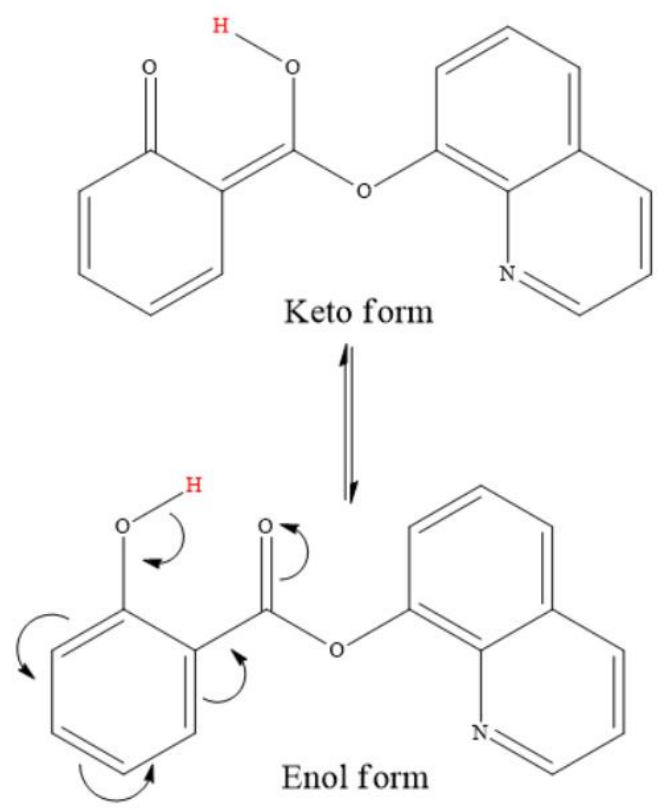

Fig. 5. Possible tautomeric forms and electron delocalization of QHB

The fluorescence spectra of QHB generally show two bands, except for methanol and ethylene glycol solvents. In these two solvents, QHB exhibits three bands, probably due to the formation of strong inter-molecular H-bonding between QHB and alcoholic solvents. The second band $\left(\lambda_{\mathrm{PL}-2}\right)$, centered in the range of 399-461 nm (see Table 1), arose from the electron conjugation by the induction of electrons over the molecule under excitation. This band can be attributed to $\pi^{*}-\pi$ electronic transitions. The third band $\left(\lambda_{\mathrm{PL}-3}\right)$ observed at $472-$ $481 \mathrm{~nm}$ is expected to appear because of interactions between the active center of QHB and solvents by the way of lone pairs located on oxygen and nitrogen atoms (see Figure 3). Intra-molecular $\mathrm{O}-\mathrm{H}-----\mathrm{O}$ interactions give rise to a ring and consequently a new charge transfer channel. This case leads to the fluorescence band splitting to be two bands and thus, the third band arises. According to these findings, the third band can be described as $\pi^{*}$-n electronic transitions.

The second fluorescence band shows a hypsochromic shift according to the increase in solvent dielectric constant. From benzene to acetonitrile, QHB shows a $62 \mathrm{~nm}$ blue shift. However, the third band does not change regularly depending on the change in solvent dielectric constant. 
Table 1

Wavelengths of absorption and fluorescence spectra of QHB molecule

\begin{tabular}{lcccccc}
\hline \hline Solvent & $\boldsymbol{\lambda}_{\text {abs-1 }}$ & $\boldsymbol{\lambda}_{\text {abs-2 }}$ & $\boldsymbol{\lambda}_{\text {abs-3 }}$ & $\boldsymbol{\lambda}_{\text {PL-1 }}$ & $\boldsymbol{\lambda}_{\text {PL-2 }}$ & $\boldsymbol{\lambda}_{\text {PL-3 }}$ \\
\hline Cyclohexane & 303 & 308 & 315 & - & 459 & 476 \\
Benzene & 303 & 308 & 315 & - & 461 & 480 \\
Toluene & 302 & 308 & 315 & - & 459 & 479 \\
Xylene & 302 & 308 & 315 & - & 460 & 480 \\
Diethyl ether & 302 & 306 & 314 & - & 459 & 481 \\
Chloroform & 301 & 306 & 314 & - & 453 & 475 \\
DCM & 302 & 307 & 314 & - & 461 & 481 \\
1-Butanol & 304 & 307 & 314 & - & 445 & 475 \\
Methanol & - & 306 & - & 361 & 445 & 472 \\
Acetonitrile & 301 & 306 & 313 & - & 399 & 480 \\
Ethylene glycol & - & 307 & - & 376 & 444 & 480 \\
\hline \hline
\end{tabular}

\subsection{Multiple linear regression analysis}

The derived LSER models by using the maximum wavenumbers $\left(v_{\max }\right)$ for both KamletTaft and Catalan solvatochromism with both absorbance and fluorescence electronic transitions of the QHB molecule are given below.

\section{Kamlet-Taft solvatochromism for absorption spectra}

$$
\begin{gathered}
v_{\max }=32970.843-1512.357 f(n)+214.489 f(\varepsilon)- \\
-55.406 \beta-58.5 \alpha \\
R=0.869 ; R^{2}=0.755 ; F=4,622 ; P=0.048 ; N=11
\end{gathered}
$$

Catalan solvatochromism for absorption spectra

$$
\begin{gathered}
v_{\max }=329898.354-595.575 S P+222.793 S d P- \\
-93.756 S A-10.102 S B \\
R=0.854 ; R^{2}=0.729 ; F=4.034 ; P=0.063 ; N=11
\end{gathered}
$$

\section{Kamlet-Taft solvatochromism for fluorescence spectra}

$$
\begin{gathered}
v_{\max }=21086.55+1395.30 f(n)+298.60 f(\varepsilon)+ \\
+560.78 \beta+378.77 \alpha
\end{gathered}
$$

$R=0.921 ; R^{2}=0.848 ; F=6.972 ; P=0.028 ; N=10$

Catalan solvatochromism for fluorescence spectra

$$
\begin{gathered}
v_{\max }=21635.34+123.18 S P+19.29 S d P+ \\
+955.222 S A+316.215 S B
\end{gathered}
$$

$R=0.932 ; R^{2}=0.869 ; F=8.278 ; P=0.020 ; N=10$

The absorption and fluorescence wavenumber values, Kamlet-Taft and Catalan parame- ters with using LSER statistical calculations of QHB molecule are listed in Table 2. In the following equations; $R$ is the correlation parameter, $R^{2}$ is the square of the linear correlation, $F$ is the Fischer standard parameter, and $P$ is the signum coefficient. If $R$ and $R^{2}$ are greater than $0.7, F$ must be greater, but if $P$ is very close to zero, we can say that, the LSER model is correct.

Model of Kamlet-Taft solvatochromism derived by using 11 solvents for absorption maximum wavenumbers is given in Eq. 4. Thus, we can say that LSER model derived from the KamletTaft parameters is appropriate according to the statistical parameters. The Catalan solvatochromic model is also derived by using 11 solvents (Eq. 5). The statistical parameters calculated for this model are in applicable values. According to Equation 4, electronic transitions in absorption spectra display a bathochromic effect by dispersion-polarization effects through a $\mathrm{C}_{1}$ sign that is negative (-).

On the contrary, the $\mathrm{C}_{2}$ sign is (+), thus electron transitions of QHB molecule exposure a hypsochromic shift with the effect of orientationinduction. However, hydrogen bond acceptor and donor effects of solvents in electronic absorption spectra are relatively small. The effect of dispersion-polarization interactions on the electronic absorption spectra of the QHB molecule is greater than the dipole-orientation interaction, because absolute $\mathrm{C}_{1}$ is bigger than absolute $\mathrm{C}_{2}$. The contributions on specific and non-specific interactions to Kamlet-Taft solvatochromism for UV spectra are calculated as $83 \%$ for refractive index function (dispersion-polarization interaction), $12 \%$ for the dielectric function (induction-orientation interac- 
tion), $3 \%$ for the H-bond acceptor capacity and 2\% for the H-bond donor capacity.

The sign of $\mathrm{C}_{6}$ coefficient in the Catalan solvatochromism (Eq. 5) is observed to be negative $(-)$; thus, there exists a bathochromic shift in the absorption band maximum. In contrast, when the $\mathrm{C}_{7}$ sign is positive (+), increasing in solvent polarity shows a hypsochromic effect in this band maximum. According to Eq. (5), solvent polarizability has a relatively higher effect on the electronic absorption bands than solvent polarity because $\mathrm{C}_{6}$ is bigger than $\mathrm{C}_{7}$. The case $|\mathrm{C} 8|>|\mathrm{C} 9|$ indicates that solvent acidity is more effective than solvent basicity. In addition, the rate of effect of $S P, S d P, S A$ and $S B$ has been calculated as $65 \%, 24 \%, 10 \%$ and $1 \%$, respectively, from Eq. (5).

Eqs. 6 and 7 show LSER models derived for the maximum fluorescence wavenumbers by using 10 solvents. Acetonitrile has not been included in these equations because it deviated from the linearity. Thus, statistical parameters obtained for these solvatochromic models are derived in acceptable values. The fluorescence wavenumbers in the gas phase of QHB molecule are calculated as 21086.55 $\mathrm{cm}^{-1}$ and $21635.34 \mathrm{~cm}^{-1}$ in Eqs. 6 and 7. Since the $\mathrm{C}_{1}$ and $\mathrm{C}_{2}$ coefficients in Eq. 6 are positive, it can be said that the QHB molecule exposes a bathochromic shift with the effect of dispersionpolarization and orientation-induction forces. The relation of $\left|\mathrm{C}_{1}\right|>\left|\mathrm{C}_{2}\right|$ points out that dispersionpolarization interactions (refractive index function) are observed to be more dominant than orientationinduction interactions (dielectric function) on the fluorescence spectral band shifts. Specific interactions $(\alpha$ and $\beta$ ) effect on the electronic emission spectra is greater than the orientation-induction effect (Eq. 6). According to Eq. 6, $\left|\mathrm{C}_{3}\right|>\left|\mathrm{C}_{4}\right|$ indicates that the solvent intends to interact with the molecule by the way of $\mathrm{H}$-bonding acceptor. There is a bathochromic effect since the sign of the $\mathrm{C}_{3}$ and $\mathrm{C}_{4}$ coefficients are (+). The contribution of each of the solvent parameter in Kamlet Taft solvatochromism for fluorescence spectra is determined to be $52 \%$ for the diffraction function (dispersionpolarization interaction), $12 \%$ for the dielectric function (induction-orientation interaction), 22\% for the $\mathrm{H}$ bond acceptor capacity and $14 \%$ for the $\mathrm{H}$ bond donor capacity.

As seen from Eq. 7, the solvent polarizability effect on the fluorescence spectra of the QHB molecule is much greater than the effect of the solvent dipolarity. Since the coefficients of both parameters are positive, there is a bathochromic shift in molecules. The effect of solvent acidity is bigger than that of solvent basicity. These solvent parameters also support the bathochromic effect. The impact factors of each solvent parameter on fluorescence spectral shifts determined from the Catalan solvatochromism are 9\%, 1\%, 68\% and $22 \%$ for solvent polarizability $(S P)$, solvent dipolarity $(S d P)$, solvent acidity $(S A)$ and solvent basicity $(S B)$, respectively.

\section{T a ble 2}

The absorbance wavenumbers, fluorescence wavenumbers, Kamlet-Taft and Catalan parameters using LSER statistical calculations of QHB molecule [10, 30]

\begin{tabular}{|l|cc|ccccccc|ccc|}
\hline \hline Solvent & Wavelength & \multicolumn{7}{|c|}{ Kamlet-Taft parameters } & \multicolumn{4}{c|}{ Catalan parameters } \\
\hline & $v_{\mathrm{abs}}$ & $v_{\mathrm{pl}}$ & $\varepsilon$ & $n$ & $\alpha$ & $\beta$ & $f(n)$ & $f(\varepsilon)$ & $S P$ & $S d P$ & $S A$ & $S B$ \\
\hline Cyclohexane & 32467 & 21786 & 2.02 & 1.4262 & 0 & 0 & 0.3408 & 0.3377 & 0.683 & 0 & 0 & 0.073 \\
Benzene & 32467 & 21691 & 2.27 & 1.5011 & 0 & 0.100 & 0.3852 & 0.3883 & 0.793 & 0.270 & 0 & 0.124 \\
Toluene & 32467 & 21786 & 2.38 & 1.4969 & 0 & 0.128 & 0.3828 & 0.4082 & 0.782 & 0.284 & 0 & 0.128 \\
Xylenes & 32467 & 21739 & 2.56 & 1.5055 & 0 & 0.157 & 0.3877 & 0.4382 & 0.791 & 0.266 & 0 & 0.157 \\
Diethylether & 32679 & 21786 & 4.20 & 1.3524 & 0 & 0.562 & 0.2930 & 0.6153 & 0.617 & 0.385 & 0 & 0.562 \\
Chloroform & 32679 & 22075 & 4.89 & 1.4459 & 0.047 & 0.071 & 0.3528 & 0.6604 & 0.783 & 0.614 & 0.047 & 0.071 \\
DCM & 32573 & 21691 & 8.93 & 1.4242 & 0.040 & 0.178 & 0.3395 & 0.7985 & 0.761 & 0.769 & 0.040 & 0.178 \\
1-Butanol & 32573 & 22471 & 17.51 & 1.3993 & 0.341 & 0.809 & 0.3238 & 0.8919 & 0.674 & 0.655 & 0.341 & 0.809 \\
Methanol & 32679 & 22471 & 32.66 & 1.3284 & 0.930 & 0.620 & 0.2765 & 0.9405 & 0.608 & 0.904 & 0.605 & 0.545 \\
Acetonitrile & 32679 & 25062 & 35.94 & 1.3441 & 0.190 & 0.310 & 0.2873 & 0.9458 & 0.645 & 0.974 & 0.044 & 0.286 \\
Ethylene glycol & 32573 & 22522 & 37.7 & 1.4318 & 0.900 & 0.520 & 0.3442 & 0.9483 & 0.777 & 0.910 & 0.717 & 0.534 \\
\hline \hline
\end{tabular}




\subsection{Non-linear optical properties}

Non-linear optical (NLO) effects emerge from the interactions of electromagnetic fields in various media to generate new fields changed in phase, frequency, amplitude or other diffusion characteristics from the incident fields [41]. NLO materials have been widely investigated by researchers recently due to their importance in applicability as the key functions of frequency shifting, optical logic, optical switching, optical modulation and optical memory for the upcoming technologies in areas of telecommunications, signaling and optical interconnections [42-45].

A Taylor series expansion of the total dipole moment, $\mu_{\text {tot }}$, (Eq. 8) induced by the field represents the NLO response of an isolated molecule in an electric field $\mathrm{E}_{\mathrm{i}}(\omega)$ :

$$
\mu_{\mathrm{tot}}=\mu_{0}+\alpha_{\mathrm{ij}} E_{\mathrm{j}}+\beta_{\mathrm{ijk}} E_{\mathrm{jk}}+\ldots
$$

where $\alpha, \mu_{0}$ and $\beta_{\mathrm{ijk}}$ are linear polarizability, the permanent dipole moment and the first hyperpolarizability tensor, respectively. The isotropic (or average) linear polarizability can be calculated by Eq. (9) [46]:

$$
\alpha_{\mathrm{tot}}=\left(\alpha_{\mathrm{xx}}+\alpha_{\mathrm{yy}}+\alpha_{\mathrm{zz}}\right) / 3
$$

The first hyperpolarizability is a third degree tensor that is represented by $3 \times 3 \times 3$ matrix. The 27 elements of the 3D matrix can be reduced to 10 components due to the Kleinman symmetry [46] such that $\left.\beta_{x y y}=\beta_{y x y}=\beta_{y y x}=\beta_{y y z}=\beta_{y z y}=\beta_{z y y} ; \ldots\right)$. The output file of a computation in Gaussian 09 provides 10 values of this matrix as $\beta_{\mathrm{xxx}}, \beta_{\mathrm{xxy}}, \beta_{\mathrm{xyy}}$, $\beta_{\mathrm{yyy}}, \beta_{\mathrm{xxz}}, \beta_{\mathrm{xyz}}, \beta_{\mathrm{yyz}}, \beta_{\mathrm{xzz}}, \beta_{\mathrm{yzz}}$, and $\beta_{\mathrm{zzz}}$, respectively. The components of the first hyperpolarizability can be calculated using the following equation (Eq. 10) [47]:

$$
\beta_{\mathrm{i}}=\beta_{\mathrm{iii}}+1 / 3 \Sigma\left(\beta_{\mathrm{ijj}}+\beta_{\mathrm{jij}}+\beta_{\mathrm{jij}}\right)
$$

The magnitude of $\beta_{\text {tot }}$ from Gaussian program output can be calculated by Eq. 11 .

$$
\begin{gathered}
\beta_{\mathrm{tot}}=\left[\left(\beta_{\mathrm{xxx}}+\beta_{\mathrm{xyy}}+\beta_{\mathrm{xzz}}\right)^{2}+\left(\beta_{\mathrm{yyy}}+\beta_{\mathrm{yzz}}+\beta_{\mathrm{yxx}}\right)^{2}+\right. \\
\left.+\left(\beta_{\mathrm{zzz}}+\beta_{\mathrm{zxx}}+\beta_{\mathrm{zyy}}\right)^{2}\right]^{1 / 2}
\end{gathered}
$$

The calculations of the total molecular dipole moment $\left(\mu_{\text {tot }}\right)$, linear polarizability $\left(\alpha_{\text {tot }}\right)$ and hyperpolarizability $\left(\beta_{\text {tot }}\right)$ from the Gaussian output were explained in a previous work [48], and DFT has been widely used as an effective method to compute the properties of NLO materials [49]. The electronic dipole moment $\mu_{\mathrm{tot}}$, polarizability $\alpha_{\mathrm{tot}}$ and the hyperpolarizability $\beta_{\text {tot }}$ data of all compounds were calculated at the B3LYP/6-
$311+\mathrm{G}(\mathrm{d}, \mathrm{p})$ level of theory using the Gaussian 09 package; results are given in Table 3 .

Table 3

The B3LYP/6-311+G(d,p) calculated dipole moment $\mu_{\text {tot }}$ (Debye), the average polarizability $\alpha_{\text {tot }}$ $\left(A^{3}\right)$ and the first hyperpolarizability $\beta_{\text {tot }}\left(\times 10^{-30} \mathrm{~cm}^{5} / \mathrm{esu}\right)$ for $\mathrm{QHB}$

\begin{tabular}{lr|lr}
\hline \hline$\mu_{x}$ & -2.919 & $\beta_{x x x}$ & -582.877106 \\
$\mu_{y}$ & -0.450 & $\beta_{x x y}$ & -71.987416 \\
$\mu_{z}$ & -1.897 & $\beta_{x y y}$ & -37.330918 \\
$\mu_{\text {tot }}$ & 3.510 & $\beta_{y y y}$ & 64.559404 \\
$\alpha_{x x}$ & 269.679 & $\beta_{x x z}$ & 157.755952 \\
$\alpha_{x y}$ & 7.995 & $\beta_{x y z}$ & 42.741979 \\
$\alpha_{y y}$ & 204.118 & $\beta_{y y z}$ & -63.491717 \\
$\alpha_{x z}$ & -15.755 & $\beta_{x z z}$ & 17.509357 \\
$\alpha_{y z}$ & 0.707 & $\beta_{y z z}$ & -21.848597 \\
$\alpha_{z z}$ & 151.831 & $\beta_{z z z}$ & -196.248420 \\
$\alpha_{\text {tot }}$ & 30.9 & $\beta_{\text {tot }}$ & 5.3 \\
\hline \hline
\end{tabular}

The dipole moments of 8-hydroxyl quinoline and QHB have been calculated to be 2.8 and 3.5 Debye, respectively. Hydroxy benzoate attached to the parent quinoline results in an increase in charge separation; thus, observation of a greater dipole moment is not surprising. Dipole moment vectors calculated for both 8-hydroxyl quinoline and QHB in the ground state are depicted in Figure 6.

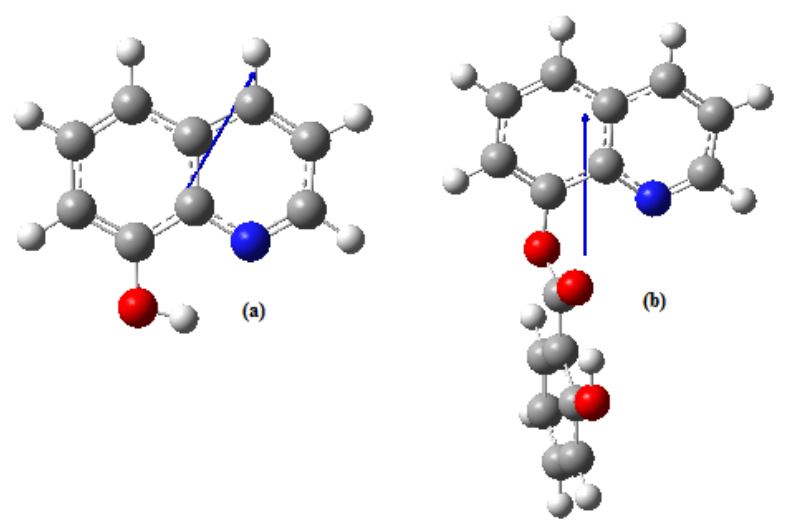

Fig. 6. The ground state dipole moment vectors calculated by B3LYP/6-311+G(d,p) for 8-hydroxyquinoline and QHB

The 3D-MEP surface counter maps were obtained for B3LYP/6-311+G(d,p) optimized geometries to predict reactive sites for electrophilic and nucleophilic processes for the compounds and dipole moment observations. The electrostatic potential surface of QHB is shown in Figure 7. Electrophilic reactivity regions (negative charge) are shown 
by red and yellow colors, while blue is an indicator of nucleophilic reactivity [50]. For the title compound, the negative charge is mostly localized on the electron withdrawing hydroxyl benzoate region, as expected. The charge separation is very well observed for QHB, which may be the reason for the high magnitude dipole moment (Fig. 7).

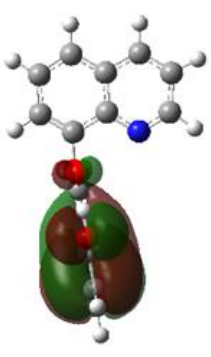

HOMO (-6.44)

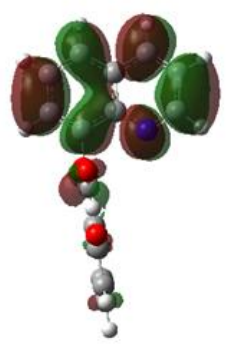

$\operatorname{LUMO}(-2.02)$

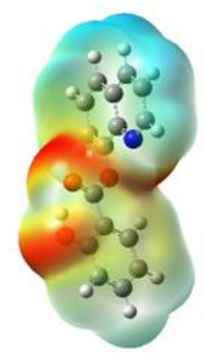

Fig. 7. Frontier molecular orbitals (energies in eV) and MEP for QHB calculated by B3LYP/6-311+G(d,p)

The average polarizability $\left(\alpha_{\mathrm{tot}}\right)$ data, together with its components are listed in Table 3. The value of the calculated polarizability is equal to $30.9 \AA^{3}$ for QHB. Hyperpolarizability data $\beta_{\text {tot }}(5.3$ $\times 10^{-30} \mathrm{~cm}^{5} / \mathrm{esu}$ ) for the compound is found to be much greater than that of urea $\left(0.77 \times 10^{-30}\right.$ $\mathrm{cm}^{5} / \mathrm{esu}$ ) [51], which is one of the typical compounds used in research into the NLO properties of molecular systems. Therefore, it was used frequently as a threshold value for comparative studies [51]. The obtained results show that the title compound is a good candidate for NLO materials. Hyperpolarizability data for hydroxyquinoline itself was computed to be 3.5 ; thus, an increase in the conjugation path upon substitution of the benzoate link and other groups resulted in an increase in first hyperpolarizability. Comparison of interfrontier energy gap data with the hyperpolarizability values is a good indicator of nonlinear properties. $\Delta E$ for urea was calculated to be $8.2 \mathrm{eV}$ at the same level of the DFT method, whereas the $\Delta E$ values for the present system are $4.42 \mathrm{eV}$.

The Highest Occupied Molecular Orbital (HOMO) implies the outermost filled orbital and behaves as an electron donor; on the other hand, Lowest Unoccupied Molecular Orbital (LUMO) can be considered as the unfilled orbital with the lowest energy and behaves as an electron acceptor. HOMO and LUMO are also called the frontier molecule orbitals (FMOs). The energy gap between FMOs gives information about the chemical stability of a molecule and is an important parame- ter in terms of electronic transport properties. In Figure 7, FMO energies (in $\mathrm{eV}$ ) and threedimensional HOMO and LUMO energy schemes for QHB are given. HOMO and LUMO are located on the hydroxy benzoate and quinoline parts of the structure, respectively. The computed HOMO and LUMO energies for QHB are $-6.44 \mathrm{eV}$ and -2.02 $\mathrm{eV}$. The energy gap $\left(\Delta E=E_{\mathrm{LumO}}-E_{\mathrm{HOMO}}\right)$ is found to be $4.42 \mathrm{eV}$.

\subsection{TDDFT calculations}

The vertical excitation energies and oscillator strengths were obtained for the 100 lowest singlet transitions at the optimized ground state equilibrium geometries by using TDDFT with the CAM-B3LYP/6-311+G(d,p) level of theory [40]. Optimized ground state structures were utilized to obtain the electronic absorption spectra, including maximum absorption wavelengths, oscillator strengths, and main configuration assignments by using TDDFT. Although there are some exceptions, information in the literature suggests that analysis of the excitation energies with CAMB3LYP functionally predicts the best agreement with the experimental data [52].

The theoretically calculated absorption spectra of QHB in the gas phase and various solvents are given in Figure 8. Three strong bands of absorption are observed for QHB at 145, 206 and 275 $\mathrm{nm}$. The absorption characteristics did not show strong dependence on solvent type. However, differences in the emission spectra are expected. It is clear that the solvent gives rise to a red shift in UV spectra compared to that in the gas phase due to the specific and non-specific solute and solvent interactions. In these interactions, the electronic transitions occur between special states.

The results of the TDDFT/CAM-B3LYP/6$311+\mathrm{G}(\mathrm{d}, \mathrm{p})$ calculations for QHB are given in Table 4. Transition coefficients, absorption wavelengths, oscillator strengths, excitation energies and orbitals involved in transitions are tabulated in the gas phase, in methanol and in benzene. The three absorption maxima in the gas phase are 272.58, 221.59, and $210.40 \mathrm{~nm}$. In methanol and benzene, absorption bands are located at 279.77 , 280.94, 228.63, 228.81, 213.70 and $216.47 \mathrm{~nm}$, respectively. In conclusion, although absorption wavelengths are almost independent of the solvent type and polarity, a red shift from the gas phase calculations exists due to the involvement of solute-solvent interactions in IEFPCM computations. 


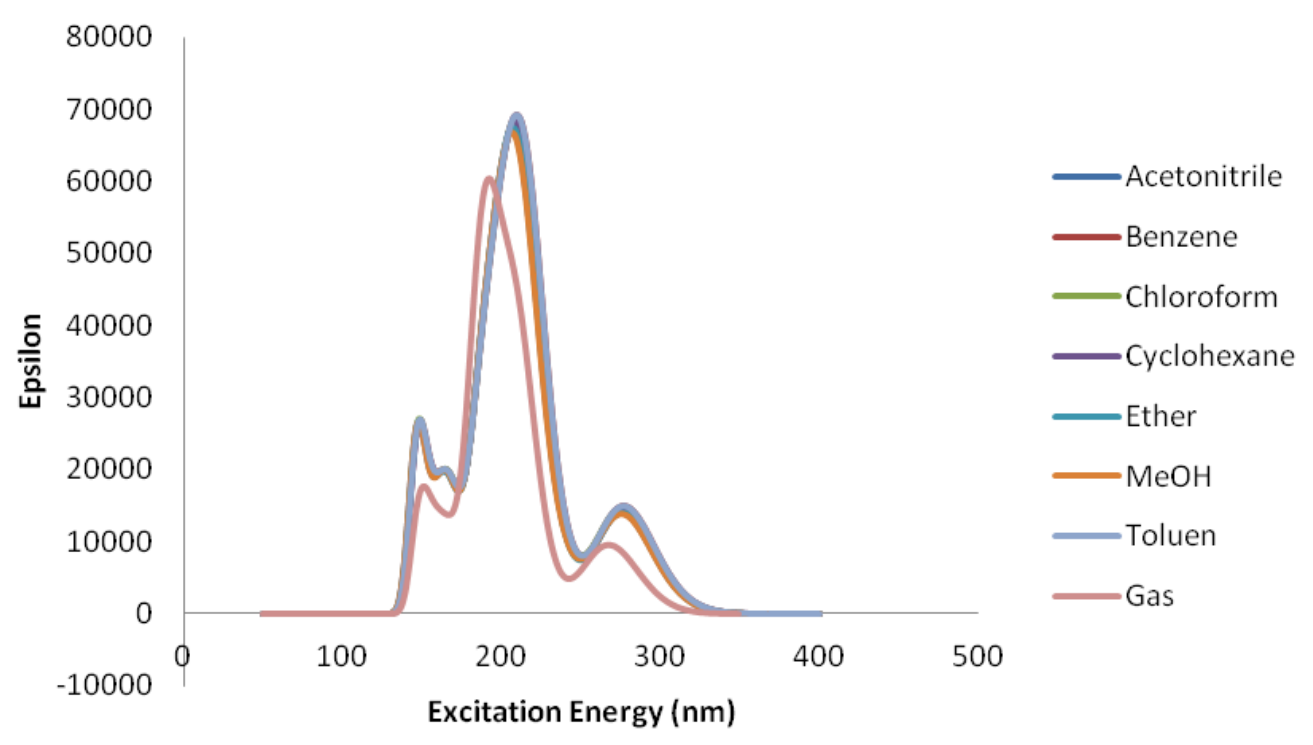

Fig. 8. TD-CAM-B3LYP/6-311+G(d,p) calculated UV spectra for QHB

Table 4

B3LYP/6-311+G(d,p) calculated absorption wavelengths ( $\lambda_{\max }$ in $\left.\mathrm{nm}\right)$, excitation energies $(\mathrm{eV})$ and oscillator strengths $(f)$ for $Q H B$ in gas phase, $\mathrm{MeOH}$ and benzene

\begin{tabular}{llcccc}
\hline \hline \multirow{2}{*}{ Gas } & Transition & Transition coefficients & $\lambda_{\max }$ & Excitation energy & Oscillator strength \\
\hline \multirow{3}{*}{ MeOH } & $\mathrm{H} \rightarrow \mathrm{L}$ & 0.64118 & 272.58 & 4.5485 & 0.1435 \\
& $\mathrm{H}-3 \rightarrow \mathrm{L}+1$ & 0.45114 & 221.59 & 5.5952 & 0.1259 \\
& $\mathrm{H} \rightarrow \mathrm{L}+2$ & 0.46933 & 210.40 & 5.8929 & 0.7034 \\
\hline \multirow{3}{*}{ Benzene } & $\mathrm{H} \rightarrow \mathrm{L}+1$ & 0.44322 & 279.77 & 4.4316 & 0.2300 \\
& $\mathrm{H}-3 \rightarrow \mathrm{L}+1$ & 0.52120 & 228.63 & 5.4230 & 0.1775 \\
& $\mathrm{H}-1 \rightarrow \mathrm{L}+2$ & 0.36921 & 213.70 & 5.8017 & 0.8969 \\
\hline \hline & $\mathrm{H} \rightarrow \mathrm{L}+1$ & 0.61599 & 280.94 & 4.4133 & 0.2523 \\
& $\mathrm{H}-3 \rightarrow \mathrm{L}+1$ & 0.50904 & 228.81 & 5.4187 & 0.1512 \\
& $\mathrm{H}-1 \rightarrow \mathrm{L}+2$ & 0.44574 & 216.47 & 5.7275 & 0.7898 \\
\hline
\end{tabular}

\section{CONCLUSIONS}

A novel quinolin-hydroxybenzoate derivative was synthesized with a very high yield and its various physical, chemical and electronic properties were investigated, both experimentally and theoretically. It is observed that the global electronic transitions consist of mix of $\pi-\pi^{*}$ and $n-\pi^{*}$ electronic transitions. The Kamlet-Taft solvatochromic model indicates that dispersionpolarization forces effectively control the spectral shifts of absorption and fluorescence spectra. The solvatochromic model of Catalan designates that solute-solvent interaction is governed by solvent polarity in absorption spectra and by solvent acidity in fluorescence spectra. Non-specific interaction parameters show a bathochromic effect for the absorption spectral bands. The similar behavior is observed for fluorescence band. Thus, the QHB molecule is found to be more stable in the ground state than in the excited state. The results of the computational calculations showed that the most stable conformer of the title compound, QHB, involves intra-molecular hydrogen bonding. The possible formation of intra-molecular hydrogen bonding on different sites of the structure leads to other minima. However, conformation with the absence of hydrogen bonding is found to possess the highest energy. The potential of use QHB as a non-linear optical material has been suggested by NLO calculations. Both experimental and calculated vertical excitation data of QHB indicate three main absorption bands for the title compound.

Acknowledgements: We are grateful to the Presidency of Scientific Research Projects of Van Yuzuncu Yil University for financial support (2017-FEN-B326). The authors greatly acknowledge the support of Bitlis Eren University, Scientific and Technological Application and Research Center. 


\section{REFERENCES}

[1] H. R. P. Naik, H. S. B. Naik, T. R. R. Naik, H. R. Naika, K. Gouthamchandra, R. Mahmood, B. M. K. Ahamed, Synthesis of novel benzo[h]quinolines: Wound healing, antibacterial, DNA binding and in vitro antioxidant activity, Eur. J. Med. Chem. 44, 981-989 (2009).

[2] Y. Hirano, M. Uehara, K. Saeki, T. Kato, K. Takahashi, T. Mizutani, The influence of quinolines on coumarin 7 hydroxylation in bovine liver microsomes and human CYP2A6, J. Health Sci. 48, 118-125 (2002).

[3] S. Bawa, S. Kumar, Synthesis of Schiff's bases of 8methyl-tetrazolo[1,5-a]quinoline as potential antiinflammatory and antimicrobial agents, Indian J. Chem. 48B, 142-145 (2009).

[4] P. R. Graves, J. J. Kwiek, P. Fadden, R. Ray, K. Hardeman, A. M. Coley, M. Foley, T. A. J. Haystead, Discovery of novel targets of quinoline drugs in the human purine binding proteome, Mol. Pharmacol. 62, 1364-1372 (2002).

[5] R. Musiol, J. Jampilek, K. Kralova, D. R. Richardson, D. Kalinowski, B. Podeszwa, J. Finster, H. Niedbala, A. Palka, J. Polanski, Investigating biological activity spectrum for novel quinoline analogues, Bioorg. Med. Chem. 15, 1280-1288 (2007).

[6] L. S. Hunga, C. H. Chen, Recent progress of molecular organic electroluminescent materials and devices, Mater. Sci. Eng. R, 39, 143-222 (2002).

[7] C. H. Chen, J. Shi, Metal chelates as emitting materials for organic electroluminescence, Coord. Chem. Rev., 171, 161-174 (1998).

[8] K. Ch. Song, J. S. Kim, S. M. Park, K.-Ch. Chung, S. Ahn, S.-K. Chang, Fluorogenic $\mathrm{Hg}^{2+}$-selective chemodosimeter derived from 8-hydroxyquinoline, Org. Lett., 8, 3413-3416 (2006).

[9] H. Zhang, Q.-L. Wang, Y.-B. Jiang, 8-Methoxyquinoline based turn-on metal fluoroionophores, Tetrahedron Lett., 48, 3959-3962 (2007).

[10] C. Reichardt, Solvents and Solvent Effects in Organic Chemistry, 2nd ed., Wiley-VCH, Weinheim, 1988, p. 285.

[11] C. Reichardt, Solvatochromism, thermochromism, piezochromism, halochromism, and chiro-solvatochromism of pyridinium N-phenoxide betaine dyes. Chem. Soc. Rev. 21, 147-153 (1992).

[12] A. Maiti, A. Svizhenko, M. P. Anantram, Electronic Transport through Carbon Nanotubes: Effects of Structural Deformation and Tube Chirality, Phys. Rev. Lett. 88, 1268051-1268054 (2002).

[13] D. Zhou, D. Ma, Yan Wang, Xianchun Liu, Xinhe Bao, Study with density functional theory method on methane $\mathrm{C}-\mathrm{H}$ bond activation on the $\mathrm{MoO}_{2} / \mathrm{HZSM}-5$ active center, Chem. Phys. Lett. 373, 46-51 (2003).

[14] J. Leconte, A. Markovits, M. K. Skalli, C. Minot, A. Belmajdoub, Periodic ab initio study of the hydrogenated rutile $\mathrm{TiO}_{2}\left(\begin{array}{lll}1 & 1 & 0\end{array}\right)$ surface, Surf. Sci. 497, 194-204 (2002).
[15] J. Wang, C. Liu, Z. Fang, Y. Liu, Z. Han, DFT study of structural and electronic properties of PdO/HZSM-5, $J$. Phys. Chem. B, 108, 1653-1659 (2004).

[16] M. Szafran, A. Komasa, E. B. Adamska, Crystal and molecular structure of 4-carboxypiperidinium chloride (4-piperidinecarboxylic acid hydrochloride), J. Mol. Struct. 827, 101-107 (2007).

[17] M. Karabacak, Z. Calisir, M. Kurt, E. Kose, A. Atac, The spectroscopic (FT-IR, FT-Raman, dispersive Raman and NMR) study of ethyl-6-chloronicotinate molecule by combined density functional theory, Spectrochim. Acta A, 153, 754-770 (2016).

[18] M. Toy, H. Tanak, Molecular structure and vibrational and chemical shift assignments of 3'-chloro-4dimethylamino azobenzene by DFT calculations, Spectrochim. Acta A, 152, 530-536 (2016).

[19] D. S. Chemla, J. Zyss, Non-linear Optical Properties of Organic Molecules and Crystals, Academic Press, New York, 1987.

[20] A. Kawski, Progress in Photochemistry and Photophysics, CRC Press, New York, 1994, p. 1-47.

[21] L. V. Haley, H. F. Hameka, Calculation of molecular electric polarizabilities and dipole moments. II. $\mathrm{LiH}$ molecule, Int. J. Qunat. Chem. 11, 733-741 (1977).

[22] J. Jayabharathi, V. Thanikachalam, K. Jayamoorthy, Physicochemical studies of chemosensor imidazole derivatives: DFT based ESIPT process, Spectrochim. Acta A, 89, 168-176 (2012).

[23] J. Jayabharathi, V. Thanikachalam, M. Vennila, K. Jayamoorthy, Potential fluorescent chemosensor based on L-tryptophan derivative: DFT based ESIPT process, Spectrochim. Acta A, 95, 446-451 (2012).

[24] D. R. Lide (Ed.), CRC Handbook of Chemistry and Physics, 80th ed., CRC Press, Boca Raton, 1999.

[25] C. Reichardt, Solvents and Solvent Effects in Organic Chemistry, 3rd edition, WILEY-VCH Verlag GmbH \& Co. KGaA, Weinheim, 2003.

[26] W. M. Haynes (Ed.), CRC Handbook of Chemistry and Physics, 96th ed., CRC Press, Taylor and Francis, Boca Raton, FL, 2015-2016.

[27] M. J. Kamlet, J. L. Abboud, M. H. Abraham, R. W. Taft, Linear solvation energy relationships. 23. A comprehensive collection of the solvatochromic parameters, .pi.*, .alpha., and .beta., and some methods for simplifying the generalized solvatochromic equation, $J$. Org. Chem. 48, 2877-2887 (1983).

[28] M. J. Kamlet, J. L. Abboud, R. W. Taft, The solvatochromic comparison method. 6. The .pi.* scale of solvent polarities, J. Am. Chem. Soc. 99, 6027-6038 (1997).

[29] Y. Marcus, The properties of organic liquids that are relevant to their use as solvating solvents, Chem. Soc. Rev. 22, 409-416 (1993).

[30] J. Catalan, Toward a Generalized Treatment of the Solvent Effect Based on Four Empirical Scales: Dipolarity (SdP, a New Scale), Polarizability (SP), Acidity (SA), and Basicity (SB) of the Medium, J. Phys. Chem. B, 113, 5951-5960 (2009). 
[31] İ. Sidır, Y. Gülseven Sidır, H. Berber, F. Demiray, Emerging ground and excited state dipole moments and external electric field effect on electronic structure. A solvatochromism and theoreticcal study on 2((phenylimino)methyl)phenol derivativers. Journal of Molecular Liquids, 206, 56-67 (2015).

[32] S. Gandhimathi, C. Balakrishnan, R. Venkataraman, M.A. Neelakantan, Crystal structure, solvatochromism and estimation of ground and excited state dipole moments of an allyl arm containing Schiff base: Experimental and theoretical calculations. Journal of Molecular Liquids, 219, 239-250 (2016).

[33] J. Catalan, J. P. Catalan, On the solvatochromism of the $\mathrm{n} \leftrightarrow \pi^{*}$ electronic transitions in ketones, Phys. Chem. Chem. Phys. 13, 4072-4082 (2011).

[34] W. Kohn, L.J. Sham, Self-consistent equations including exchange and correlation effects. Phys. Rev. 140, 11331138 (1965).

[35] M. J. Frisch, G. W. Trucks, H. B. Schlegel, G. E. Scuseria, M. A. Robb, J. R. Cheeseman, G. Scalmani, V. Barone, B. Mennucci, G. A. Petersson, H. Nakatsuji, M. Caricato, X. Li, H. P. Hratchian, A. F. Izmaylov, J. Bloino, G. Zheng, J. L. Sonnenberg, M. Hada, M. Ehara, K. Toyota, R. Fukuda, J. Hasegawa, M. Ishida, T. Nakajima, Y. Honda, O. Kitao, H. Nakai, T. Vreven, J. A. Montgomery, Jr., J. E. Peralta, F. Ogliaro, M. Bearpark, J. J. Heyd, E. Brothers, K. N. Kudin, V. N. Staroverov, T. Keith, R. Kobayashi, J. Normand, K. Raghavachari, A. Rendell, J. C. Burant, S. S. Iyengar, J. Tomasi, M. Cossi, N. Rega, J. M. Millam, M. Klene, J. E. Knox, J. B. Cross, V. Bakken, C. Adamo, J. Jaramillo, R. Gomperts, R. E. Stratmann, O. Yazyev, A. J. Austin, R. Cammi, C. Pomelli, J. W. Ochterski, R. L. Martin, K. Morokuma, V. G. Zakrzewski, G. A. Voth, P. Salvador, J. J. Dannenberg, S. Dapprich, A. D. Daniels, O. Farkas, J. B. Foresman, J. V. Ortiz, J. Cioslowski, and D. J. Fox, Gaussian 09, Revision D.01, Gaussian, Inc., Wallingford CT, 2013.

[36] A. D. Becke, Density-functional exchange-energy approximationwith correct asymptotic behavior. Phys. Rev. A, 38, 3098-3100 (1988).

[37] C. Lee, W. Yang, R.G. Parr, Development of the ColleSalvetti correlation energy formula into a functional of the electron density. Phys. Rev. B, 37, 785-789 (1988).

[38] C. Amovilli, V. Barone, R. Cammi, E. Cances, M. Cossi, B. Mennucci, C. S. Pomelli, J. Tomasi, Recent advances in the description of solvent effects with the polarisable continuum model, Adv. Quantum Chem. 32, 227-261 (1998).

[39] M. E. Casida, C. Jamorski, K. C. Casida, D. R. Salahub, Molecular excitation energies to high-lying bound states from timedependent density-functional response theory: characterization and correction of the time-dependent local density approximation ionization threshold. $J$. Chem. Phys. 108, 4439-4449 (1998).
[40] Y. X. Sun, Q. L. Hao, W. X. Wei, Z. X. Yu, L. D. Lu, X. Wang, Y. S. Wang, Experimental and density functional studies on 4-(3,4-dihydroxybenzylideneamino) antipyrine, and 4-(2,3,4-trihydroxybenzylideneamino) antipyrine, J. Mol. Struct.:Theochem 904, 74-82 (2009).

[41] C. Andraud, T. Brotin, C. Garcia, F. Pelle, P. Goldner, B. Bigot, A. Collet, Theoretical and experimental investigations of the nonlinear optical properties of vanillin, polyenovanillin, and bisvanillin derivatives, $J$. Am. Chem. Soc. 116, 2094-2102 (1994).

[42] V. M. Geskin, C. Lambert, J. L. Bredas, Origin of high second- and third-order nonlinear optical response in ammonio/borato diphenylpolyene zwitterions: the remarkable role of polarized aromatic groups, J. Am. Chem. Soc. 125, 15651-15658 (2003).

[43] M. Nakano, H. Fujita, M. Takahata, K. Yamaguchi, Thheoretical study on second hyperpolarizabilities of phenylacetylene dendrimer: toward an understanding of structure-property relation in NLO responses of fractal antenna dendrimers, J. Am. Chem. Soc. 124, 9648-9655 (2002).

[44] D. Sajan, H. Joe, V.S. Jayakumar, J. Zaleski, Structural and electronic contributions to hyperpolarizability in methyl p-hydroxy benzoate, J. Mol. Struct. 785, 43-53 (2006).

[45] R. Zhang, B. Du, G. Sun, Y. X. Sun, Experimental and theoretical studies on $\mathrm{o}-, \mathrm{m}-\mathrm{and} \mathrm{p}-$ chlorobenzylideneaminoantipyrines, Spectrochim. Acta A, 75, 1115-1124 (2010).

[46] D. A. Kleinman, Nonlinear dielectric polarization in optical media, Phys. Rev. 126, 1977-1979 (1962).

[47] K. S. Thanthiriwatte, K. M. Nalin de Silva, Non-linear optical properties of novel fluorenyl derivatives - ab initio quantum chemical calculations, J. Mol. Struct.:Theochem 617, 169-175 (2002).

[48] H. Tanak, K. Pawlus, M. K. Marchewka, A. Pietraszko, Structural, vibrational and theoretical studies of anilinium trichloroacetate: New hydrogen bonded molecular crystal with nonlinear optical properties, Spectrochim. Acta Part A, 118, 82-93 (2014).

[49] H. Tanak, A. A. Agar, O. Buyukgungor, Experimental (XRD, FT-IR and UV-Vis) and theoretical modeling studies of Schiff base (E)-N'-((5-nitrothiophen-2yl)methylene)-2-phenoxyaniline, Spectrochim. Acta Part A, 118, 672-682 (2014).

[50] H. Tanak, Molecular structure, spectroscopic (FT-IR and UV-Vis) and DFT quantum-chemical studies on 2-[(2,4dimethylphenyl)iminomethyl]-6-methylphenol, $\mathrm{Mol}$. Phys. 112, 1553-1565 (2014).

[51] S. M. Yanez, S. A. Moya, C. Zuniga, G. C. Jiron, Theoretical assessment of TD-DFT applied to a ferrocene-based complex. Comput Theor Chem 1118, 65-74 (2017). 